УДК 616.716.4-001.5-08:159.923

DOI 10.11603/2311-9624.2017.2.7962

\author{
(СЯ. П. Нагірний, В. Л. Фесик
}

ДВНЗ «Тернопільський державний медичний університет імені І. Я. Горбачевського»

\title{
Особливості перебігу загоєння переломів нижньої щелепи в осіб із різним психосоматичним типом особистості
}

Резюме. Останніми роками в літературі з'явились дані про взаємозв’язок виникнення ускладнень у постраждалих із травматичними переломами нижньої щелепи з лабільністю їх психіки. Однак у доступній літературі ми не знайшли публікацій, у яких висвітлювались би результати досліджень щодо особливостей перебігу загоєння кісткових ран у осіб із різним психосоматичним типом особистості. Мета дослідження - вивчити особливості перебігу загоєння кісткових ран при переломах нижньої щелепи в осіб із різним психосоматичним типом особистості.

Матеріали і методи. Дослідження особливостей перебігу загоєння переломів нижньої щелепи проведено у 54 постраждалих різного психосоматичного типу особистості за Айзенком, серед яких: екстраверти - 32 і 22 - інтроверти. Клінічно вивчали інтенсивність запальної реакції, вираження больового синдрому, структуру ускладнень.

Результати досліджень та їх обговорення. Встановлено, що клінічні прояви переломів в осіб-екстравертів і осіб-інтровертів мали свої особливості. Вираження запальної реакції було меншим в осібекстравертів, що проявлялось більш швидкими темпами зменшення болю, набряку, інфільтрації м'яких тканин. При оцінці больового синдрому за Verbal Descriptor Scale встановлено, що група постраждалих інтровертів була більш чутлива до болю. Зниження інтенсивності больових відчуттів у ділянці перелому в них відбувалось повільніше. Гнійні запальні ускладнення частіше виникали у постраждалих інтровертів. Суттєвих відмінностей у структурі запальних ускладнень у порівнюваних групах не було.

Висновки. Результати клінічних спостережень вказують, що перебіг загоєння кісткових ран при травматичних переломах нижньої щелепи в осіб із різним психосоматичним типом особистості має свої особливості. Встановлено, що вираження запальної реакції м’яких тканин у ділянці перелому була меншою в постраждалих екстравертів, порівняно з інтровертами, останні були більш чутливими до болю, у них частіше виникали гнійні ускладнення.

Ключові слова: травматичні переломи нижньої щелепи; перебіг загоєння; екстраверти; інтроверти.

(С). П. Нагирный, В. Л. Фесик

ГВУз «Тернопольский государственный медицинский университет имени И. Я. Горбачевского»

\section{Особенности течения заживления переломов нижней челюсти у лиц с разным психосоматическим типом личности}

Резюме. В последние годы в литературе появились данные о взаимосвязи возникновения осложнений у пострадавших с травматическими переломами нижней челюсти с лабильностью их психики. Однако в доступной литературе мы не нашли публикаций, в которых освещались бы результаты исследований особенностей течения заживления костных ран у лиц с различным психосоматическим типом личности.

Цель исследования - изучить особенности течения заживления костных ран при переломах нижней челюсти у лиц с различным психосоматическим типом личности.

Материалы и методы. Исследование особенностей течения заживления переломов нижней челюсти проводили у 54 пострадавших разного психосоматического типа личности по Айзенку, среди которых: экстраверты - 32, 22 - интроверты. Клинически изучали интенсивность воспалительной реакции, выраженность болевого синдрома, структуру осложнений.

Результаты исследований и их обсуждение. Установлено, что клинические проявления переломов у лиц-экстравертов и лиц-интровертов имели свои особенности. Выраженность воспалительной реакции была меньше у лиц-экстравертов, что проявлялось более быстрыми темпами уменьшения боли, отека, инфильтрации мягких тканей. При оценке болевого синдрома по Verbal Descriptor Scale 
установлено, что группа пострадавших интровертов была более чувствительна к боли. Снижение интенсивности болевых ощущений в области перелома у них происходило медленнее. Гнойные воспалительные осложнения чаще возникали в пострадавших интровертов. Существенных различий в структуре воспалительных осложнений в сравниваемых группах не было.

Выводы. Результаты клинических наблюдений указывыют, что течение процесса заживления костных ран при травматических переломах нижней челюсти у лиц с различным психосоматическим типом личности имеет свои особенности. Установлено, что выраженность воспалительной реакции мягких тканей в области перелома была меньше в пострадавших экстравертов, по сравнению с интровертами, последние были более чувствительными к боли, у них чаще возникали гнойные осложнения.

Ключевые слова: травматические переломы нижней челюсти; течение заживления; экстраверты; интроверты.

CYa. P. Nahirniy, V. L. Fesyk

I. Horbachevsky Ternopil State Medical University

\section{The features of the course of healing of the mandible fractures in persons with various psychosomatic type of personality}

Summary. Recently, the literature data about the relationship between the occurrence of complications in traumatic fractures of the mandible injured with the labiality of their psyche were appeared. However, in accessible literature, we did not find publications that would highlight the results of research on the features of the course of healing bone wounds in persons with different psychosomatic type of personality.

The aim of the study - to learn the features of the course of healing bone wounds in fractures of the mandible in persons with different psychosomatic type of personality.

Materials and Methods. The study of the features of the course of healing of the mandible fractures was carried out in 54 injured of different psychosomatic type of personality by Eysenck, among whom there were 32 extraverts and 22 introverts. The intensity of the inflammatory response, severity of the pain syndrome and structure of complications were studied clinically.

Results and Discussion. It was established that the clinical signs of fractures in people-extroverts and introverts have their own characteristics. Severity of inflammatory response was lower in people extroverts, which manifested itself more rapidly of pain reducing, of swelling and soft tissue infiltration. In evaluated pain for Verbal Descriptor Scale we had found that introverts group of injured was more sensitive to pain. Reducing the intensity of pain in the fracture site in them was slower. The purulent inflammatory complications were more often among injured introverts. There were no significant differences in the structure of inflammatory complications in the comparable groups.

Conclusions. The results of clinical observations indicate that the course of healing bone wounds in persons with traumatic fractures of the mandible and different psychosomatic type of personality has its own characteristics. It was established that the severity of the inflammatory reaction of soft tissues in the fracture area in the injured extroverts was less than introverts, the latter were more sensitive to pain, they often had purulent complications.

Key words: traumatic fractures of the mandible; the course of healing; extroverts; introverts.

Вступ. Останнє десятиліття характеризується неухильним зростанням кількості невогнепальних травм щелепно-лицевої ділянки (щлд) - 16,5 \% усіх травм [1, 2]. Це пов’язано із зростанням техногенності суспільства та збереження соціальної напруги в ньому [3]. Серед переломів кісток лицевого черепа у 70-80 \% випадків зустрічаються переломи нижньої щелепи. Контингент таких хворих досягає 40,0 \% від загальної кількості стаціонарних хворих стоматологічного профілю $[4,5]$. Незважаючи на постійне вдосконалення та впровадження в клінічну практику методів комплексного лікування переломів нижньої щелепи, частота ускладнень залишається високою і складає $35-41,0 \%[6,7]$.

В останні роки з'явились окремі публікації [8-10], у яких встановлено, що певний відбиток на перебіг загоєння кісткових ран накладають особливості психосоматичного стану пацієнта. Вважається, що ускладнення перебігу репаративного остеогенезу частіше виника- 
ють в осіб із лабільною психікою. Л. І. Волошина, О. Є. Рибалов констатують, що в кожного третього постраждалого серед інтровертів виникає травматичний остеомієліт, тоді як у екстравертів лише у кожного десятого [12]. Це свідчить, що генетично запрограмований психічний статус $є$ індикатором особливостей обміну речовин, імунного статусу i, зокрема, перебігу репаративного остеогенезу [11, 12]. Однак у доступній літературі ми не знайшли публікацій, у яких висвітлювались би результати досліджень щодо особливостей перебігу загоєння кісткових ран в осіб із різним психосоматичним типом особистості.

Метою дослідження було вивчити особливості перебігу загоєння кісткових ран при переломах нижньої щелепи в осіб із різним психосоматичним типом особистості.
Матеріали і методи. Для вирішення поставлених завдань у відділенні хірургічної стоматології КЗ ТОР «Тернопільська університетська лікарня» проведено клінічне спостереження перебігу загоєння переломів у 54 осіб різного психосоматичного типу особистості. Тип особистості постраждалих визначали за тестами опитувальника Айзенка і відповідно постраждалих поділили на дві групи: екстраверти (перша група, 32 особи), інтроверти (друга група, 22 особи). Досліджували інтенсивність запальної реакції в ділянці перелому, величину больового синдрому, структуру ускладнень.

Результати досліджень та ї обговорення. Динаміку клінічних симптомів прояву запальної реакції в ділянці перелому представлено в таблиці 1.

таблиця 1. Результати оцінки клінічних симптомів запальної реакції в осіб із різним психосоматичним типом особистості

\begin{tabular}{|l|c|c|}
\hline \multirow{2}{*}{ Клінічний симптом } & \multicolumn{2}{|c|}{ Час спостереження, дні } \\
\cline { 2 - 3 } & екстраверти, $\mathrm{n}=32$ & інтроверти, $\mathrm{n}=22$ \\
\hline Біль & $5,8 \pm 0,2$ & $6,0 \pm 0,3$ \\
\hline Набряк & $3,7 \pm 0,3$ & $4,2 \pm 0,2^{*}$ \\
\hline Інфільтрат & $4,7 \pm 0,8$ & $5,2 \pm 0,5$ \\
\hline Підвищення температури тіла & $2,0 \pm 0,2$ & $2,4 \pm 0,3^{*}$ \\
\hline
\end{tabular}

Примітка.* - різниця достовірна при р<0,05 за критерієм Стьюдента.

Результати клінічних спостережень свідчать, що зменшення болю, набряку, інфільтрації м’яких тканин проходило більш швидкими темпами в екстравертів. У них раніше нормалізувалася температура тіла.

Представляє інтерес більш детальне вивчення характеру больових відчуттів у постраждалих різних груп. Для оцінки больового синдрому ми використали шкалу Verbal Descriptor Scale [13]. Відповідно до неї, виділяється шість варіантів оцінки больового синдрому: немає болю - 0 балів; слабкий біль - 2 бали; помірний біль - 4 бали; сильний біль - 6 балів; дуже сильний біль - 8 балів; нестерпний біль - 10 балів. Характер больового синдрому в постраждалих першої групи представлений у таблиці 2.

Як видно із даних таблиці 2, в першу добу після травми серед обстежених постраждалих першої групи (екстраверти) не було осіб, які б не відзначали болю у ділянці травми, 7 постраждалих вказували на слабкий біль, 23 - помірний, 2 - сильний. На 3 добу больові відчуття зовсім щезли у 3 постраждалих, 29 скаржились на слабкий біль. На 7-й день після травми не зареєстровано жодних больових відчуттів у 27 постраждалих, на слабкий біль вказали 5 осіб.

Серед інтровертів картина вираження больового синдрому була дещо іншою (табл. 3).

Таблищя 2. Оцінка больового синдрому в постраждалих першої групи (екстраверти, n=32)

\begin{tabular}{|c|c|c|c|c|c|c|}
\hline \multirow{2}{*}{ Доба } & \multicolumn{7}{|c|}{ Бали } \\
\cline { 2 - 7 } & 0 & 2 & 4 & 6 & 8 & 0 \\
\hline 1 & 0 & 7 & 23 & 2 & 0 & 0 \\
\hline 3 & 3 & 29 & 0 & 0 & 0 & 0 \\
\hline 7 & 27 & 5 & 0 & 0 & 0 & 0 \\
\hline
\end{tabular}


Таблищя 3. Оцінка больового синдрому в постраждалих другої групи (інтроверти, n=22)

\begin{tabular}{|c|c|c|c|c|c|c|}
\hline \multirow{2}{*}{ Доба } & \multicolumn{7}{|c|}{ Бали } \\
\cline { 2 - 7 } & 0 & 2 & 4 & 6 & 8 & 10 \\
\hline 1 & 0 & 2 & 17 & 3 & 0 & 0 \\
\hline 3 & 0 & 10 & 12 & 0 & 0 & 0 \\
\hline 7 & 9 & 11 & 2 & 0 & 0 & 0 \\
\hline
\end{tabular}

Серед інтровертів на першу добу після травми 3 постраждалих скаржились на сильний біль у ділянці перелому. Найбільшою була група, у яких больовий синдром був помірно виражений - 17, слабкий біль був у 2 постраждалих. На третю добу після травми помірний біль відмічали 12 постраждалих, слабкий - 10.

Якщо порівнювати вираження больового синдрому в двох групах, то слід відзначити, що група постраждалих інтровертів була більш чутливою до болю. Зниження інтенсивності больових відчуттів у них відбувалось повільніше. Так, 3 постраждалих цієї групи навіть на 7-й день після травми відмічали помірний біль у ділянці перелому, а зникнення больових відчуттів на 7-й день після травми був лише у 9 постраждалих.

Характер і кількість запальних ускладнень представлені в таблиці 4.
Серед постраждалих обох досліджуваних груп спостерігались як випадки гладкого загоєння кісткових ран, так і випадки виникнення гнійних ускладнень. У 25 (78,12 \%) осіб першої групи i у 15 (68,19 \%) осіб другої групи ускладнень не було. У решти хворих обох груп загоєння переломів супроводжувалось різними ускладненнями. Нагноєні гематоми навколощелепних тканин були у 2 (6,25 \%) постраждалих першої групи і у 2 (9,09 \%) постраждалих другої групи. Первинного нагноєння кісткової рани не було зареєстровано у спостережуваних групах постраждалих. Абсцеси білящелепних тканин були у 3 (9,38 \%) постраждалих першої групи і у 3 (13,63 \%) постраждалих другої. Флегмони білящелепних тканин відповідно у 2 (6,25 \%) постраждалих першої групи і в 1 (4,54 \%) - другої. Гострий посттравматичний остеомієліт розвинувся в одного постраждалого другої групи, що склало 4,54%.

Таблиця 4. Кількість і характер запальних ускладнень переломів нижньої щелепи в осіб із різним психосоматичним типом особистості

\begin{tabular}{|c|c|c|c|c|}
\hline \multirow{3}{*}{ Характер ускладнень } & \multicolumn{4}{|c|}{ Кількість ускладнень } \\
\hline & \multicolumn{2}{|c|}{ перша група, n=32 } & \multicolumn{2}{|c|}{ друга група n=22 } \\
\hline & абс. & $\%$ & абс. & $\%$ \\
\hline Нагноєна гематома білящелепних тканин & 2 & 6,25 & 2 & 9,09 \\
\hline Первинне нагноєння кісткової рани & - & - & - & - \\
\hline Абсцес білящелепних тканин & 3 & 9,38 & 3 & 13,63 \\
\hline Флегмона білящелепних тканин & 2 & 6,25 & 1 & 4,54 \\
\hline Гострий посттравматичний остеомієліт & - & - & 1 & 4,54 \\
\hline Усього & 7 & 21,88 & 7 & 31,81 \\
\hline
\end{tabular}

Висновки. Загоєння переломів нижньої щелепи в осіб різного психосоматичного типу особистості має свої особливості. В екстравертів зменшення болю, набряку, інфільтрації м'яких тканин у ділянці перелому проходить більш швидкими темпами. У них раніше нор-

\section{Список літератури}

1. Рибачук А. В. Обгрунтування комплексного застосування і профілактики гнійно-запальних ускладнень травматичних переломів нижньої щелепи місцевим застосуванням субстанції наночастинок малізується температура тіла. Вираження больового синдрому більша в інтровертів. Зниження інтенсивності больових відчуттів у них проходить повільніше і вища частота гнійних ускладнень.

срібла і золота: автореф. дис. на здобуття наук. ступеня канд. мед. наук : спец. 14.01.22 «Стоматологія» / Національний медичний університет ім. О. О. Богомольця. - К., 2016. - 20 с. 


\section{Хірургічна стоматологія}

2. Переломи нижньої щелепи: аналіз частоти виникнення, локалізації та ускладнень / Д. С. Аветіков, К. П. Локес, С. О. Ставицький [та ін.] // Вісник проблем біології і медицини. - 2014. - Вип. 3(3). - С. 62-64. 3. Нагірний Я. П. Шляхи оптимізації репаративного остеогенезу у хворих з травматичними переломами нижньої щелепи : автореф. дис. на здобуття наук. ступеня д-ра мед. наук : спец.14.01.22 «Стоматологія»/ Національний медичний університет ім. О. О. Богомольця. - К., 2009. - 32 с.

4. Нагірний Я. П. Якісний та кількісний склад мікрофлори порожнини рота у хворих 3 травматичними переломами нижньої щелепи / Я. П. Нагірний // Biсник проблем біології і медицини. - 2014. - Т. 1, вип. 3. C. 242-247.

5. Травматичні переломи нижньої щелепи з 1995 по 2009 рр. : матеріали клініки кафедри / В. О. Маланчук, А. В. Копчак, М. А. Городійчук [та ін.] // Вісник стоматології. - 2015. - № 1. - С. 69-73.

6. Трифаненко С. І. Спосіб лікування переломів нижньої щелепи з гнійно-запальними ускладненнями із застосуванням нікелід-титанових імплантатів / С. І. Трифаненко, О. Л. Кушнір, Л. В. Кузняк // Клінічна стоматологія. - 2014. - № 4. - С. 52-54.

7. Лікування гнійно-запальних захворювань м'яких тканин та пошкоджень нижньої щелепи / О. О. Тимо-

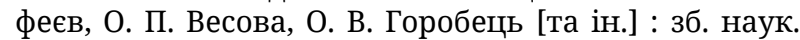

\section{References}

1. Rybachuk, A.V. (2016). Obgruntuvannia kompleksnoho zastosuvannia i profilaktyky hniino-zapalnykh uskladnen travmatychnykh perelomiv nyzhnoi shchelepy mistsevym zastosuvanniam substantsii nanochastynok sribla i zolota [Substantiation of complex application and prophylaxis of purulent-inflammatory complications of traumatic fractures of the mandible by local application of substance of silver and gold nanoparticles] Candidate's thesis. O.O. Bohomolets National Medical University, Kiyv [in Ukrainian].

2. Avetikov, D.S., Lokes, K.P., \& Stavytskyi S.O. (2014). Perelomy nyzhnoi shchelepy: analiz chastoty vynyknennia, lokalizatsii ta uskladnen [Fractures of the mandible: analysis of the frequency of occurrence, localization and complications]. Visnyk problem biolohii i medystyny Journal of the Problems of Biology and Medicine, 3 (3), 62-64 [in Ukrainian].

3. Nahirnyi, Ya.P. (2009). Yakisnyi ta kilkisnyi sklad mikroflory porozhnyny rota u khvorykh z travmatychnymy perelomamy nyzhnoi shchelepy [Ways of optimization of reparative osteogenesis in patients with traumatic fractures of the mandible]. Doctor's Extended abstract. O.O. Bohomolets National Medical University, Kiyv [in Ukrainian].

4. Nahirnyi, Ya.P. (2014). Yakisnyi ta kilkisnyi sklad mikroflory porozhnyny rota u khvorykh z travatychnymy perelomamy nyzhnoi shchelepy [Qualitative and quantitative composition of the microflora of the oral cavity in patients with traumatic fractures of the mandible]. Visnyk problem biolohii i medytsyny - Journal of Biological and Medical Problems, 1 (3), 242-247 [in Ukrainian]. 5. Malanchuk, V.O., Kopchak, A.V., \& Horodiychuk, M. (2015). Travmatychni prelomy nyzhnoi shchelepy z 1995 po 2009 rr.: materialy kliniky praktyky [Traumatic frac- праць співробітників КМАПО ім. П. Л. Шупика. - К., 2002. - Вип. № 11, кн. 3. - С. 451-459.

8. Горленко О. В. Оцінка психологічного стану хворих 3 травматичними пошкодженнями обличчя / О. В. Горленко, С. С. Поліщук, А. В. Кузько // Вісник Вінницького державного медичного університету. 2002. - № 1. - С. 67-69.

9. Юрченко В. М. Психічні стани людини: системний опис : монографія / В. М. Юрченко. - Рівне, 2006. - 574 с. 10. Поліщук С. С. Травми щелепно-лицевої ділянки та їх зв'язок з психоемоційним станом людини і типом обличчя / С. С. Поліщук // Вісник морфології. 2003. - № 9(1). - С. 147-150.

11. Можливості використання пірацетаму у хворих на травматичний остеомієліт нижньої щелепи 3 явищами стресорних реакцій / Л. І. Волошина, О. В. Рибалов, М. Г. Сінкевич [та ін.] // Український стоматологічний альманах. - 2013. - № 5. - С. 50-53.

12. Волошина Л. І. Клініко-імунологічні та психоемоційні розлади в патогенезі травматичного остеомієліту / Л. І. Волошина, О. Є. Рибалов // Галицький лікарський вісник. - 2005. - Т. 12, № 3. - С. 24-26.

13. Similarities in pain descriptions of four different ethnic-culture groups / F. Gaston-Johanson, M. Albert, E. Fagan [et al.] // J. Pain Symptom Manage. - 1990. Vol. 5 (2). - P. 94-100.

tures of the mandible from 1995 to 2009: materials of the clinic of the department)]. Visnyk stomatolohii-Journal of Dentistry, 1, 69-73 [in Ukrainian].

6. Tryfanenko, S.I., Kushnir, O.L., \& Kuzniak, L.V. (2014). Sposib likuvannia perelomiv nyzhnoi shchelepy z hniino-zapalnymy uskladnenniamy iz zastosuvanniam nikelid-tytanovykh implantiv [A method of treatment of fractures of the mandible with suppurative and inflammatory complications with the use of nickel-titanium implants]. Klinichna stomatolohiia - Clinical Dentistry, (4), 52-54 [in Ukrainian].

7. Timofeev, O., Vesova, O.P., \& Horobets, O.V. (2002). Likuvannia hniino-zapalnykh zakhvoriuvan miakykh tkanyn ta poshkodzhen nyzhnoi shchelepy [Treatment of purulent-inflammatory diseases of soft tissues and damages of the mandible]. Zb. nauk. prats spivrobitnykiv KMAPO im. P.L. Shupyka - Collection of Scientific Works of the Employees of P.L. Shupyk KMAPGE, 11 (3), 451-459 [in Ukrainian].

8. Horlenko, O.V., Polishchuk, S.S., \& Kuzko, A.V. (2002). Otsinka psykholohichnoho stanu khvorykh z travmatychnymy poshkodzhenniamy oblychchia [Assessment of the psychological state of patients with traumatic face injuries]. Visnyk Vinnytskoho derzhavnoho medychnoho universytetu - Journal of Vinnytsia State Medical University, (1), 67-69 [in Ukrainian].

9. Yurchenko, V.M. (2006). Psykhichni stany liudyny: systemnyi opys: monohrafiia [Mental states of a man: system description: monograph] Rivne [in Ukrainian]. 10. Polishchuk, S.S. (2003). Travmy shchelepno-lytsevoi dilianky ta yikh zviazok z psykhoemotsiinym stanom liudyny i typom oblychchia [Injuries of the maxillofacial area and their relationship to the psycho-emotional state of a man and face type]. Visnyk 
morfolohii - Journal of Morphology, 9 (1), 147-150 [in Ukrainian].

11. Voloshyna, L.I., Rybalov, O.V., \& Sinkevych M.H. (2013). Mozhlyvosti vykorystannia piratsetamu u khvorykh na travmatychnyi osteomiielit nyzhnoi shchelepy z iavyshchamy stresornykh reaktsii [Possibilities of using piracetam in patients with traumatic osteomyelitis of the mandible with the phenomena of stress reactions]. Ukrainskyi stomatolohichnyi almanakh - Ukrainian Dental Almanac, (5), 50-53 [in Ukrainian].
12. Voloshyna, L.I., \& Rybalov, O.Ye. (2005). Klinikoimunolohichni ta psykhoemotsiini rozlady v patohenezi travmatychnoho osteomiielitu [Clinico-immunological and psychoemotional disorders in the pathogenesis of traumatic osteomyelitis]. Halytskyi likarskyi visnyk Galician Medicinal Journal, 12 (3), 24-26. [in Ukrainian]. 13. Gaston-Johanson, F., Albert, M., \& Fagan, E. (1990). Similarities in pain descriptions of four different ethnicculture groups. J. Pain Symptom Manage, 5 (2), 94-100.

Отримано 12.04.17 